\title{
미세유체역학
}

\section{나노채널에서의 전기수력학}

DOI: $10.3938 /$ PhiT. 22.038

\section{김 성 재}

\section{Electrokinetics in a Nanochannel}

Sung Jae KIM

Recent advances in MEMS and NEMS technology have enabled the development of reliable nano structures and novel nanofluidic systems. Especially, nanoscale fluid dynamics in the presence of an external electric field has led to the discovery of new fundamentals and to engineering applications that have never been demonstrated before. Perm-selectivity of nano structure is one such phenomenon, and its mechanism and practical applications are introduced here. The major function of a nanofluidic system is active ion control by using an external electric field; thus, a study of fundamental ion transport through a nanoporous junction would be useful. As engineering examples, nanofluidic systems, such as nanofluidic preconcentrators, ionic field-effect transistors and high-energy efficient desalination/purification systems, are presented.

\section{서 론}

사람의 정상 체온은 36.5도입니다. 두 손바닥이 그림 $1(\mathrm{a})$ 처 럼 적당한 간격을 가지고 떨어져 있으면 손바닥 사이의 온도 는 대략 20도 내외의 실온과 비슷하게 됩니다. 하지만 그림 1 (b)처럼 손바닥을 가깝게 가져가면 손바닥 사이의 온도는 어 떻게 될까요? 아마도 36.5 도와 20도 사이의 적절한 온도가 될 것입니다. 즉 두 손바닥 사이 공간에서의 온도는 손바닥 사이

\section{저자약력}

김성재 교수는 포스텍에서 미세유체역학 전공의 화학공학 박사(2005)로서, 미국 M.I.T.의 연구원(2005-2012)을 거쳐, 2012년부터 현재까지 서울대 학교 전기정보공학부 조교수로 재직 중이다. (gates@snu.ac.kr)
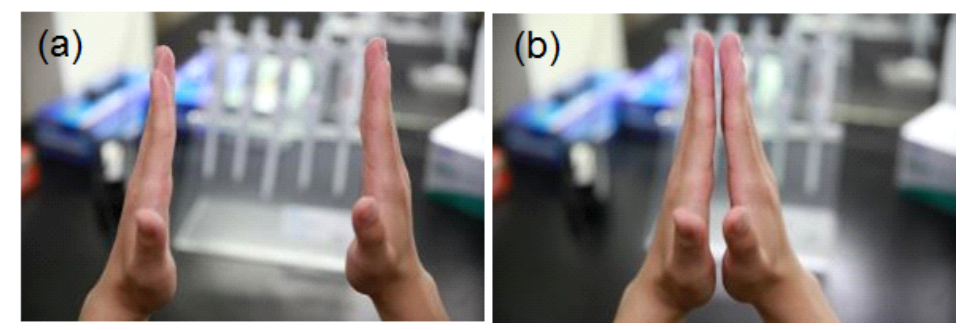

Fig. 1. Two palms are (a) a span apart and (b) close each other. The temperature in the middle of palms are significantly different in two situation.

거리에 따라 변화하게 되는 것입니다. 이러한 예를 통해 우리 는 주어진 시스템의 길이 (또는 간격)에 따라 시스템의 다른 물 성치가 변할 수 있음을 알 수 있습니다. 이번에는 온도가 아니 라 손바닥 위에 전하가 분포해 있다고 가정해보면, 손바닥 사 이의 거리가 가까워질수록 손바닥 사이 공간에 대해 전하들의 정전기력의 영향이 커질 것입니다. 따라서 그 간격이 마이크로 미터 단위 (머리카락 $100 \mu \mathrm{m}$ ), 나노미터 단위 (마이크로미터의 $1 / 1,000)$ 로 더욱 감소하게 되면 표면 전하의 영향이 더욱 강 해지게 됩니다. 이렇게 좁은 공간 속에 염 (또는 이온)을 포함 하는 전해질 용액을 주입하고 외부에서 전기장을 인가하였을 때 유체의 거동 또는 용액에 포함된 단백질, DNA 등의 입자 들의 거동을 연구하는 분야가 전기수력학(electrokinetics)입니 다. 특히 나노미터 단위의 좁은 공간에서의 전기수력학은 최근 새로운 물리적 현상이 속속 발견되며, 이를 이용한 신개념의 농축 장치, ${ }^{[1]}$ 담수/정수 장치, ${ }^{[2]}$ 액상 반도체 ${ }^{[3]}$ 등의 새로운 공 학적 응용물이 출현하게 되었습니다.

\section{REFERENCES}

[1] S. J. Kim, Y. -A. Song and J. Han, Chemical Society Reviews 39, 912 (2010).

[2] S. J. Kim, S. H. Ko, K. H. Kang and J. Han, Nature Nanotechnology 5, 297 (2010).

[3] B. Kim, J. Heo, H. Kwon, S. Cho, J. Han, S. J. Kim and G. Lim, ACS Nano 7, 740 (2013). 


\section{나노 유체역학의 새로운 물리 현상}

90년대 말 신뢰할 수 있는 나노 구조물 제작 공정이 개발됨 에 따라 마이크로 유체역학(microfluidics) 연구자들은 나노 유 체역학(nanofluidics)으로 눈길을 돌리기 시작하였습니다. 나노 미터 크기는 단백질 등 생체 물질과 비슷한 크기이므로, 연구 초반 단순히 1,000 분의 1 로 작아진 시스템의 특성 길이를 이 용한 단분자 물질의 검출 혹은 조작을 위주로 연구가 시작되 었습니다. 하지만 앞서 손바닥 예에서 보았듯이 시스템 구성 물질 표면의 영향이 더욱 더 커지게 되어 기존에는 관찰되지 않았던 전혀 새로운 물리적 현상이 발견되게 되었습니다.

좁은 폭과 넓은 폭이 반복적으로 배열된 복도에서 마른 사람 과 뚱땅한 사람이 달리기를 한다면 당연히 마른 사람이 좁은 부 분을 빨리 빠져나갈 수 있어, 최종적으로 뚱뚱한 사람보다 먼저 복도를 지나갈 수 있습니다. 복도의 크기가 마이크로미터 크기 가 되고 사람이 아닌 크기가 다른 입자인 경우에도 이러한 원리 는 적용되게 됩니다. 하지만 그 복도의 크기가 나노미터가 되면 큰 입자들이 먼저 빠져나가는 경우가 발생하게 됩니다. DNA와 같이 실타래처럼 엉켜 있는 구조체는 나노미터 크기의 좁은 부 분을 통과할 때 실타래가 풀려야만 통과가 가능합니다. 이때 작 은 입자보다는 큰 입자가 풀릴 수 있는 확률이 높아 큰 입자가 먼저 빠져나갈 수 있는 것입니다. 마치 최외곽 전자를 떼어 이 온화하는 경우, 작은 분자보다는 큰 분자의 이온화가 더 잘 되 는 것과 비슷한 원리입니다. 이는 입자의 엔트로피와 연관되어 있다 하여 엔트로피 가둠(entropic trapping)이라는 새로운 현상 으로 2000 년대 초반 명명되게 되어, ${ }^{[4]}$ 지금도 활발히 연구되고 있습니다. 이와 같이 마이크로미터 이상의 크기에서는 고려되지 않거나 무시되었던 요인들이 나노미터의 크기에서는 심각하게 고려되어야 하는 것을 실제적인 예를 들어 보겠습니다.

\section{이온 선택성}

앞서 언급했듯이 나노 구조물 표면의 전하에 의해 구조 내 부의 전해질 용액은 전기력을 받게 됩니다. 이러한 표면 전기 력이 미치는 영역을 전기이중층이라고 하며 일반적으로 전해질 농도의 루트에 반비례하는 특성 길이를 갖습니다. ${ }^{[5]}$ 전기이중 층은 대략 수 나노미터에서 수십 나노미터의 크기를 갖게 되 어, 전기이중층은 마이크로 유체역학에서 다루는 시스템에서는 무시될 수 있었지만, 전기이중층과 비슷한 특성 길이의 나노 유체역학 장치에서는 무시할 수 없고 이온 선택성이라는 독특 한 성질을 보이게 됩니다. 이는 나노 구조물 표면 전하와 반대 의 극성을 갖는 이온들만 구조물 사이로 통과시키는 성질입니 다. 이온 선택성의 원리에 대해서는 2000년대 중반까지 구조 (a)
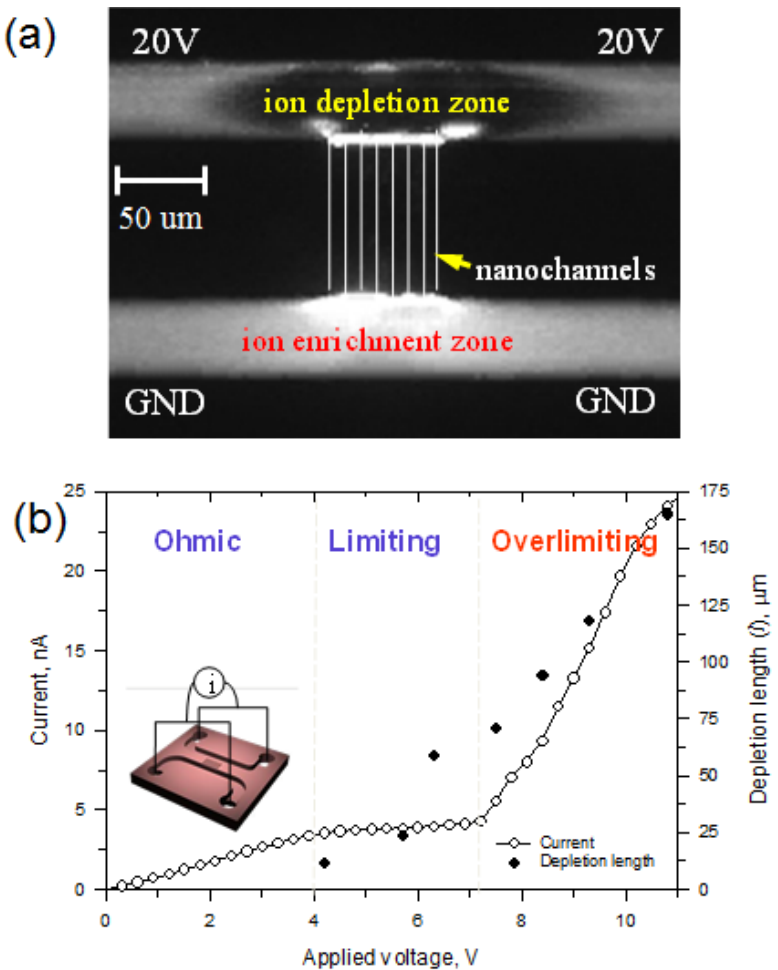

Fig. 2. (a) Ion concentration polarization phenomena occurs near nanochannel. Fluorescent signal indicates the ion depletion zone (black) and ion enrichment zone (white). (b) Ohmic-limiting-overlimiting current through nanochannel due to ion selectivity.

물 표면들에서 형성된 전기이중층이 구조물 내부에서 겹치게 되어 이온을 선택하는 것으로 알려져 있으나 후속 연구에 의 하면 나노 구조물의 표면 전위와 전해질 용액의 전기전도도의 비에 의해 결정되는 것으로 알려졌습니다.[6] 이온 선택성이라 는 현상에 대해서는 이미 오래전부터 알려져 왔지만 나노 구 조물을 정확히 제작하고 내부에서의 유체 유동 등을 가시화하 는 방법이 개발되기 시작한 2000년대 중후반부터 본격적인 연 구가 시작되었습니다.

\section{이온 농도 분극 현상}

그럼 2(a)에서 보듯이 양이온 선택성을 갖는 나노 채널이 연 결된 마이크로 채널로 전해질을 주입하고 직류 전기장을 인가 해주면 전해질의 양이온만 음극 쪽으로 나노채널을 통과하게 되고 음이온은 나노 채널을 통과하지 못하여 양극 쪽에 쌓이게 되어 이온 농도 분극(ion concentration polarization: ICP) 현

\section{REFERENCES}

[4] J. Han and H. G. Craighead, Science 288, 1026 (2002).

[5] R. F. Probstein, Physicochemical Hydrodynamics (2004).

[6] A. Mani T. A. Zangles and J. G. Santiago, Langmuir 25, 3898 (2009) 

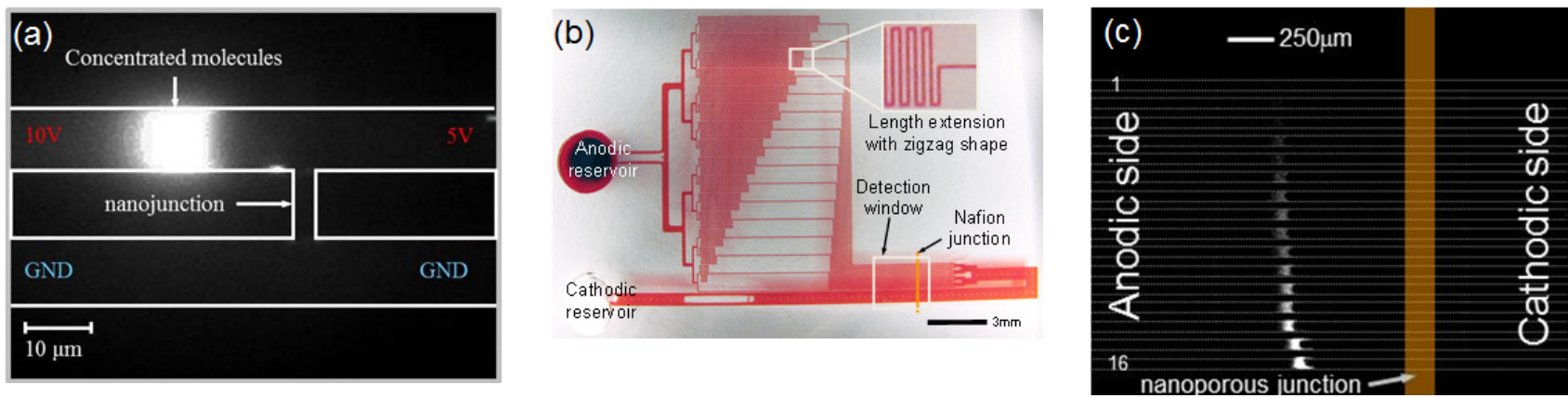

Fig. 3. (a) The operation concept of nanofluidic preconcentration device using ion concentration polarization phenomena. (b) Micro/nanofluidic channel network for multiplexed preconcentration device and (c) its operation that demonstrates a serial preconcentration.

상이 일어납니다. 이러한 상황에서 채널의 양극 쪽에는 음이온, 양이온이 모두 밀려나 매우 낮은 농도의 이온 공핍층(ion depletion zone)이 형성되며, 막의 양극 쪽에는 두 가지 이온이 모두 쌓이는 이온 농축층(ion enrichment zone)이 형성되게 됩 니다. ${ }^{[6]}$ 그림 2(a)에서 사용된 장치는 실리콘 기반의 재료로서 물과 접촉하면 음전하를 띠게 되어 양이온만을 통과시키는 이 온 선택성을 갖고, 이때 이온의 거동을 전해질 수용액에 형광 염료를 주입하여 그 거동으로 간접적으로 관찰할 수 있습니다. 이온 공핍층으로 인해 발생하는 새로운 물리적 현상은 다음과 같습니다. (1) 이온 공핍층 내부의 농도는 외부의 농도에 비해 최대 $1 / 100$ 정도 낮은 상태로 유지되기 때문에 매우 높은 전 기적 저항으로 작용하게 됩니다.[7] 일반적으로 금속 전선에 전 압을 인가할 때 전류전압 특성은 선형적인 옴의 법칙을 따르 게 됩니다. 하지만 나노 채널이 포함되어 이온 공핍층이 형성 되면 시간에 따라 전기적 저항이 급격히 증가되어 그림 2(b)에 서와 같이 낮은 전압 조건에서는 일반적인 옴의 법칙을 따르게 되지만 더 이상 전류가 증가하지 않는 한계 전류(limiting current) 영역을 거쳐 다시 증가하는 과한계 전류(over-limiting current) 영역의 비선형적 전류전압 특성을 갖게 됩니다. 이러 한 특성은 선형적 거동에 비하여 같은 전압 조건에서 낮은 전 류값을 얻게 됨을 의미합니다. 따라서 한계 전류와 과한계 전 류 영역을 제어하여 같은 전압 조건에서 높은 전류값을 얻을 수 있는 법이 활발히 연구되고 있습니다. (2) 이온 공핍층 내부 에서는 국부적으로 매우 높은 전기장이 여기됩니다. 이는 크기 가 작지만 높은 전기적 저항을 갖는 금속 전선에서 외부 전압 을 인가했을 때 저항 부분에서 대부분의 전압이 변화하는 것과 같은 원리입니다. 이로 인하여 이온 공핍층 내부에서만 전기수 력학적 유동이 급격히 빨라지게 되어, 와류를 형성하게 됩니 다. ${ }^{[8]}$ 이러한 국부적이고 빠른 와류는 시스템을 불안정화시켜 이를 극복하고자 하는 연구 또한 활발히 진행되고 있습니다. (3) 마지막으로 이온 공핍층은 낮은 농도를 유지하는 성질과 내 부의 빠른 유동으로 인하여, 내부 농도를 높일 수 있는 전하를 띤 물질의 유입을 차단합니다. 이로 인해 이온, 단백질, 적혈구,
바이러스 등의 전하를 띤 물질은 이온 공핍층을 통과할 수 없 게 됩니다. 따라서 이온 공핍층을 통과하는 전기장 또는 압력 장을 외부에서 인하하게 되면 전하를 띤 물질을 공핍층 경계에 농축시키거나, 공핍층 내부의 낮은 전해질 농도의 유체를 연속 적으로 빼내면 담수/정수 장치로 응용이 가능합니다.

\section{이온 농도 분극 현상을 이용한 이온 농축 장치}

앞서 설명한 바와 같이 이온 공핍층을 가로지르는 전기장을 인가하여 그림 3(a)에서와 같이 전하를 띠고 있는 물질을 이온 공핍층 경계에 농축시킬 수 있습니다. ${ }^{[9]}$ 전해질에 포함되어 있는 물질의 원래 농도에 비해 최대 백만 배까지 수 분 내에 농축시킬 수 있는 효과적인 농축기가 되는 것입니다. 또한 그림 3(b)와 같 이 마이크로채널 길이를 조절하여 외부 전기장을 연속적으로 상 이하게 인가하면 그림 3(c)에서 보듯이 각 위치별로 농축률이 각 기 다르도록 제어할 수 있습니다. ${ }^{[1,10]}$ 이러한 개별 제어가 가능 한 농축기는 체내에 극미량 존재하는 표지 물질들의 농도를 단 시간 내에 폭발적으로 증가시킴으로써 검출을 용이하게 할 수 있어 바이오센서 기술에 직접 적용이 가능한 기술입니다. 또한 고가의 시료를 사용하는 경우 샘플 준비 과정에서 지속적인 분 리로 인해 희석된 농도를 복귀하게 할 수 있어, 보다 고순도를 위한 분리 과정을 공격적으로 수행할 수 있도록 합니다.

\section{이온 농도 분극 현상을 이용한 담수/정수 장치}

이온 농도 분극 현상의 또 다른 이용은 공핍층 내부의 낮아

\section{REFERENCES}

[7] S. J. Kim, L. D. Li and J. Han, Langmuir 25, 7759 (2009).

[8] S. J. Kim, Y. -C. Wang, J. H. Lee, H. Chang and J. Han, Phys. Rev. Lett. 99, 044501 (2007).

[9] Y. - C. Wang, A. Stevens and J. Han, Analytical Chemistry 77, 4293 (2005).

[10] S. H. Ko, S. J. Kim, L. F. Cheow, L. D. Li, K. H. Kang and J. Han, Lab Chip 11, 1351 (2011). 

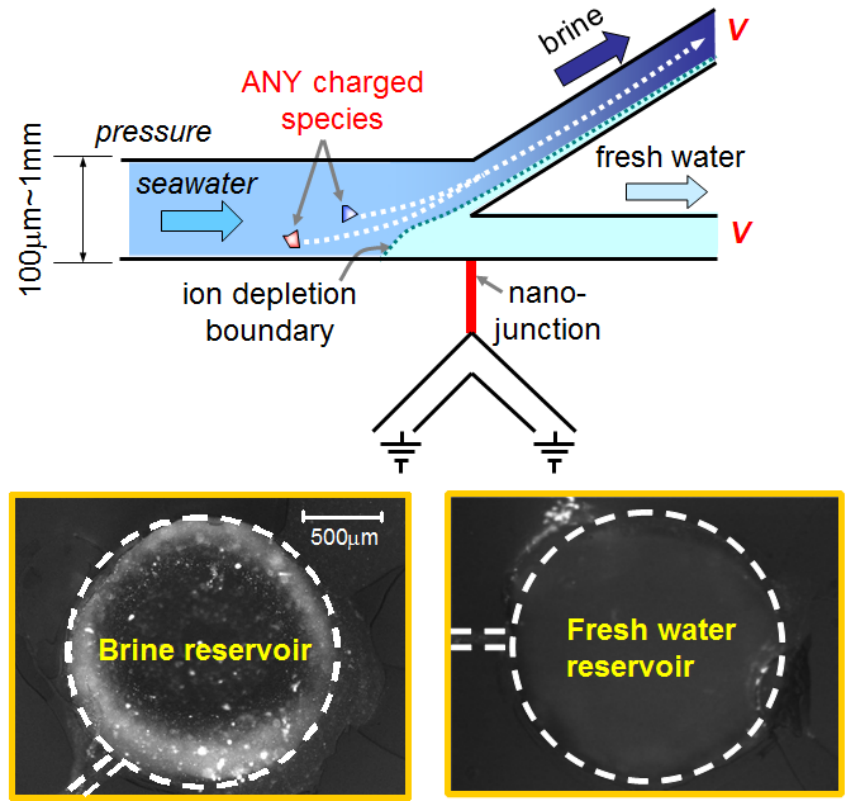

Fig. 4. Schematic diagram of desalination/purification device using ion concentration polarization phenomena and snapshots of each reservoir after an hour operation. Brine reservoir at the end of upper microchannel collects most of contaminants, while fresh water reservoir at the end of lower microchannel is clean.

진 농도의 전해질을 추출하는 기술입니다. 이는 그림 4에서 보 듯이 이온 공핍층을 통과하는 압력장과 외부 전압을 조절하여 이온 공핍층 내부의 유체가 $\mathrm{Y}$ 형태의 마이크로채널 하단으로 흐르게 하면, 전하를 띠고 있는 물질은 그 크기에 상관없이 $\mathrm{Y}$ 채널의 상단으로 밀려나게 됩니다. 해수에 포함된 염분뿐만 아 니라 대장균과 같은 세균, 혈액 속의 적혈구/백혈구, 비소와 같은 중금속 등 전하를 띠고 있는 물질을 상단으로 밀어 내기 때문에 하단의 유체는 순수한 물과 유사한 조건이 되어 담수/ 정수를 할 수 있습니다.

전 세계적으로 물 부족 사태가 심각해지면서 지구상의 풍부 한 해수를 담수로 전환하는 기술에 대한 관심이 최근 급격히 증가하고 있으며, 실제 증발식, 역삼투법 등의 방식으로 이러 한 문제점을 해결하고 있습니다. 특히 중동 지역에서는 연료 가격이 상대적으로 저렴하여 증발 방식의 담수화 공장이, 북미 /유렵 지역에서는 역삼투 방식의 담수화 공장이 건설되어 하 루에 수천 수만 톤의 담수를 생산하여 농업/공업/식용수로 활용을 하고 있습니다. 하지만 이러한 공장 규모의 장치는 소 형화시 급격한 전력 사용량의 증가 등의 이유로 인하여 기존 의 담수화 방식은 소형화가 용이하지 않습니다. 이에 비하여 휴대가 가능한 소형 담수화/정수 장치의 필요성은 의심의 여 지가 없습니다. 예를 들어 대규모 담수화 시설을 건설할 만한 경제력이 없는 후진국이나 국토가 인구에 비해 넓어 중앙 공 급식의 상수 처리가 비효율적인 곳 또는 선진국이라 하더라도 지진, 태풍 등의 자연재해에 의해 기간 시설이 파괴된 상황에
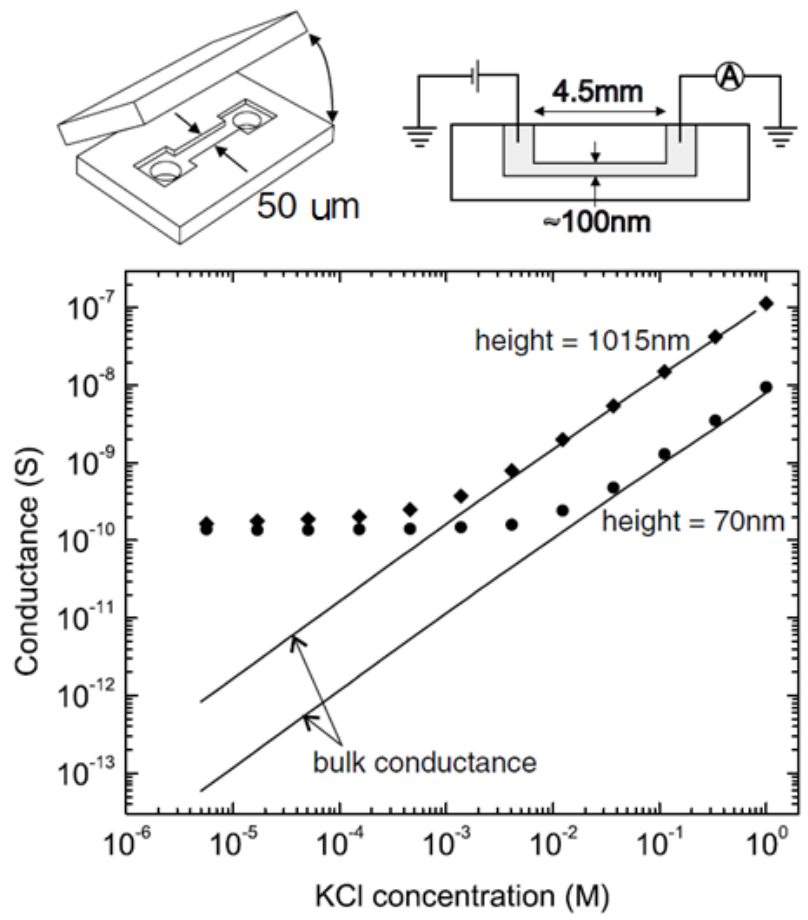

Fig. 5. The plot of Electrical conductance as a function of electrolyte concentration. The nanochannel confinment leads to a surfacecharge-governed regime (plat region) and a geometry-governed regime (linear region).

서는 소형 담수/정수화 장치의 필요성이 절실합니다. 특히 중 국, 인도, 호주와 같이 국토가 넓어 지하수를 상수원으로 사용 하는 곳에서는 산업화의 발달, 생활수준의 향상에 기인하여 급 격히 물소비가 증가하고 이에 따라 해수가 지하수를 채우게 되어, 내륙에서도 지하수가 염수화되는 현상이 최근 급격히 증 가하고 있습니다. 또한 잠수함, 항공모함과 같은 선박에서나 캠핑 용품 등의 레크리에이션 용도로서도 소형 담수화 장치는 그 가치가 큽니다. 마이크로/나노유체역학 장치의 장점은 단일 장치의 집적화를 통해 대용량화가 용이하기 때문에, 위에서 설 명한 이온 농도 분극 담수화 장치를 다중화를 통해 대용량화 하면 분당 수 리터의 담수를 생산하여 생존 문제를 해결할 수 있는 중요한 장치가 될 것으로 예상할 수 있습니다.

\section{액상 반도체}

일반적으로 전해질은 전기를 통한다고 알려져 있지만 전해질 을 담고 있는 용기의 크기가 나노미터가 되면 내부의 액체는 조 건에 따라 반도체적 성질을 갖게 됩니다. 전해질을 흐르는 전류 는 전자가 흐르는 것이 아니라 이온이 흐르는 이온 전류이기 때 문에 전해질의 농도가 높아지면 전해질의 전기적 전도도가 증가 하는 선형적 관계를 갖게 되는 것은 자명한 사실입니다. 하지만 그림 5 에서 보는 바와 같이 나노 채널에 전해질이 들어 있는 경 


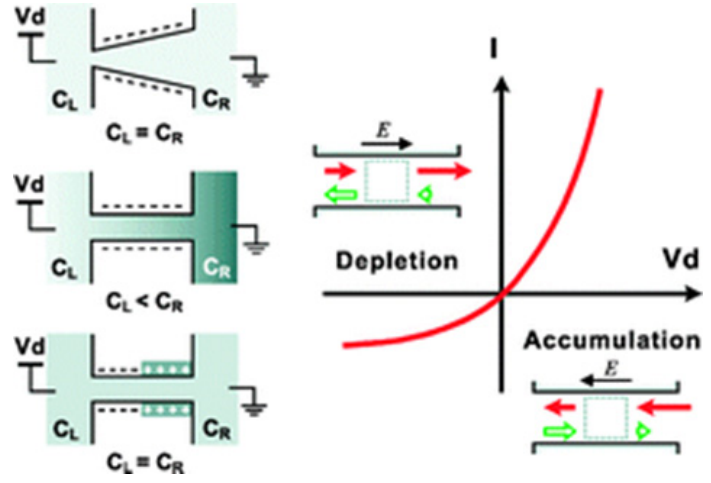

Fig. 6. Schematics of nanofluidic diode. Conical, multi concentration and bipolar type diode and their voltage-current response.

우, 전해질 농도와 전기전도도는 비선형적인 관계를 보입니다. ${ }^{[1]}$ 높은 전해질 농도에서는 나노채널의 형상에 비례하여 선형적으 로 증가하는 경향을 보이지만, 낮은 전해질 농도에서는 나노채널 재료의 전하에 의해 전류값이 고정되어 일정한 값을 갖게 됩니 다. 이러한 현상을 적절히 이용하면 나노채널의 형상 등 외부 조 건에 따라 일정 방향으로만 전류가 흐르게 되는 다이오드의 성 질을 띠게 됩니다. ${ }^{[12]}$ 그림 6 에서 보듯이 나노 채널의 형상을 깔 때기 모양으로 하거나, 나노 채널 양단에 주입되는 전해질의 농 도를 다르게 하거나, 나노 채널 내부의 전하를 표면 처리를 통해 양/음의 양극성을 띠게 하면 걸어주는 전압의 극성에 따라 나노 채널 내부의 이온이 공핍되면 역방향, 이온이 농축되면 순방향 전류가 흐르게 되어 다이오드의 특성을 갖게 됩니다.

이러한 나노 채널을 이용한 액상 다이오드의 특성을 더욱 발전시키면 액상 트랜지스터를 구현할 수 있습니다. 트랜지스 터의 원리는 게이트 전극을 설치하여 소스-드레인 전류를 게이 트 전위에 따라 조절할 수 있는 것입니다. 이를 나노 채널에 적용하면 그림 7(a)에서 보듯이 나노 포어 제작시 기질 내부에 전극을 미리 삽입하고 이를 게이트 전극으로 사용하게 되면 나노 포어를 통과하는 소스-드레인 전류값이 게이트 전압에 따 라 변화하게 됨을 관찰할 수 있습니다. ${ }^{[13]}$ 대부분의 나노 채널 혹은 나노 포어 제작에는 청정실을 사용하여 고가의 제작비가 들게 되어 이 분야 연구의 걸림돌이 되어 왔으나, 최근 고분자 물질을 이용하고 청정실 사용을 최소화하는 제작 방식에 대한 연구가 활발히 진행되면서 그림 $7(\mathrm{~b})$ 에서와 같이 고분자 물질 인 polydimethyl-siloxane(PDMS)를 이용하여도 액상 트랜지스 터의 성질을 유지할 수 있게 되었습니다.[3] 하지만 이러한 이 온 전류를 이용하는 액상 반도체는 전기적 전류를 이용하는 실제 반도체에 비하여 반응 속도가 매우 느리기 때문에 실제 집적 회로 등을 구성하는 것은 실제적 효용가치가 없습니다. 대신 이온을 종류별로 분리, 농축 등의 이온 제어 소자로 개발 하는 연구가 필요하게 됩니다.
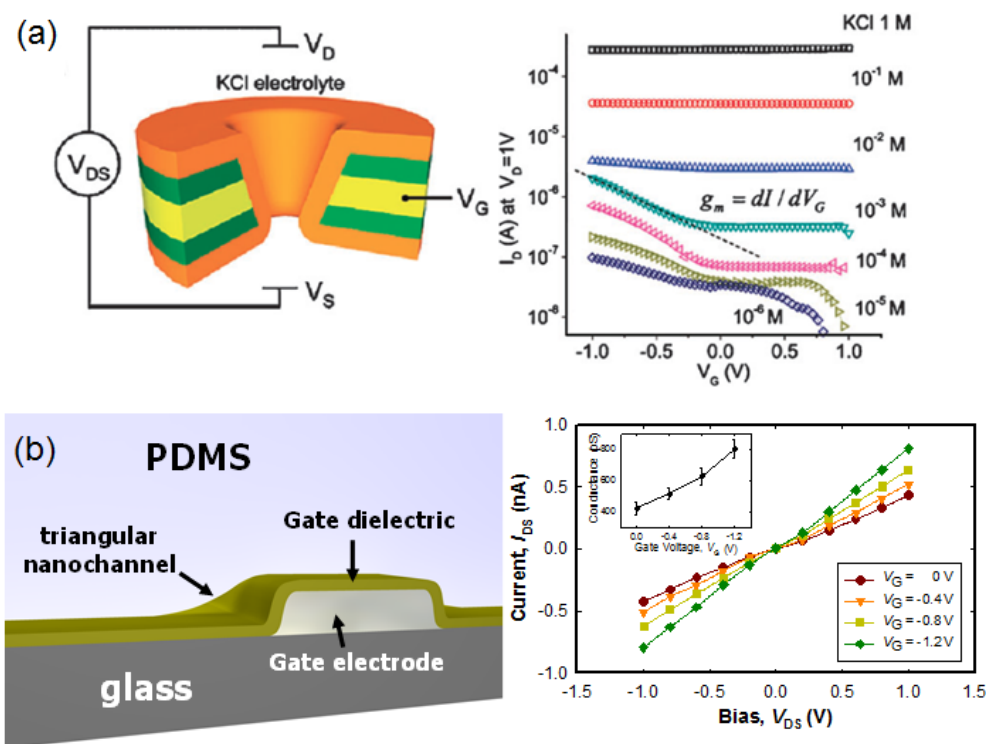

Fig. 7. (a) Schematics of nanopore based ionic transistor and its source-drain current response as a function of gate voltage. (b) Schematics of polymer-based ionic transistor and its source-drain current response as a function of gate voltage.

\section{결 론}

액체에 전기장을 인가하여 액체를 제어하는 기술은 지표의 흙 내부의 오염물을 제거하는 것으로부터 시작하여 콜로이드 입자의 거동을 연구하고 수많은 바이오 응용물을 거쳐 최근에 는 에너지 환경 문제에도 그 적용 범위를 넓혀가고 있습니다. 특히 최근 마이크로/나노 구조물 제작 방식의 발달로 신뢰할 수 있는 나노 구조물을 제작할 수 있고, 이러한 구조물에서의 나노 전기수력학에 대한 연구가 활발히 진행되고 있습니다. 기 존의 길이 단위에서는 무시되거나 나타나지 않던 새로운 물리 적 현상이 속속 발견되고 있으며 이를 설명하고자 하는 이론적 /실험적 연구 보고가 급격히 늘고 있습니다. 또한 새로운 물리 적 현상의 발견에 그치지 않고 새로운 공학적 응용물을 개발함 으로써 새로운 사회를 창조하여 인류의 삶에 이바지할 수 있는 기틀을 제공하고 있습니다. 본문에서 소개하여 드린 이온 농도 분극 현상과 이에 대한 응용물은 이러한 현상 중 하나에 불과 하며, 나노미터 크기 혹은 그 이하 세계에서는 발굴되기를 기다 리고 있는 수많은 재미있는 현상과 가치가 있다고 생각합니다.

\section{REFERENCES}

[11] D. Stein, M. Kruithof and C. Dekker, Phys. Rev. Lett. 93, 035901 (2004).

[12] L. -J. Cheng and L. J. Guo, Chemical Society Reviews 39, 923 (2010).

[13] S. -W. Nam, M. J. Rooks, K. -B. Kim and S. M. Rossnagel, Nano Letters 9, 2044 (2009). 